Indonesian Journal of Nutrition and Dietetics Vol. 6, No. 3, 2018: 99-106
Available online at: http://ejournal.almaata.ac.id/index.php/IJND DOI : http://dx.doi.org/10.21927/ijnd.2018.6(3).99-106

\title{
Intake of Iron And Inhibitor Are Not Related With Anemia On The Premarriage Women
}

\author{
Prasetya Lestari, Yhona Paratmanitya, Siti Suliyah
}

Department of Midwifery, Faculty of Health Science, Universitas Alma Ata, Jalan Brawijaya No. 99 Yogyakarta 55183, Indonesia

Deartment of Nutrition,Faculty of Health Science, Universitas Alma Ata, Jalan Brawijaya No. 99 Yogyakarta 55183, Indonesia

\begin{abstract}
Background: One of the most frequent nutritional problems in Indonesia occurs is anemia due to iron deficiency. About 49\%women of childbearing age in Indonesia are anemic. Factors causing anemia include insufficient iron intake and high absorption of Fe inhibitors (tannin, phytate, and oxalic acid). Objectives: To understand the relationship between iron intake and Fe inhibitor, and iron deficiency anemia in premarriage women in Bantul District. The study conducted was observational study using a cross sectional design. Number of subjects were 68 premarriage women selected by respondents in the bride with the picking technique the sample uses quota sampling that met the inclusion criteria and exclusion. Data collected iron intake and iron inhibitors. The data were obtained by interview using SQFFQ. Statistic analysis used were Mann Whitney test and Chi Square test with $90 \%$ level confidence.

Results: The incidence of anemia was $44.1 \%$. Based on the results there was no significant difference between the mean intake of Fe anemia group with anemia not with $(p=0.387)$. There is no Tanin intake differences were significant between the anemia group and the not anemia with $(p=0.512)$. There was no differe

nce in intake of Fitat was significant between the anemia group and the non-anemic with $(p=0.335)$. There was no significant difference in intake of xalates between groups of anemia with no anemia with ( $p$ $=0.537$ ). Based on Chi Square Test as well it was known that there is no significant relationship between intake of $\mathrm{Fe}$ and $\mathrm{Fe}$ inhibitor with anemia incidence ( $p>0.05)$

Conclusions: There was no significant relationship between intake of $\mathrm{Fe}$ and $\mathrm{Fe}$ inhibitor with anemia incidence
\end{abstract}

KEYWORDS: anemia, iron intake, inhibitor Fe, prospective bride

\section{INTRODUCTION}

One of the major malnutrition problems that occur in Indonesia is anemia. Anemia is a state of red blood cell deficiency compared to normal. This condition can be caused by blood loss or bleeding, iron deficiency ( $\mathrm{Fe}$ ) and haemolytic anemia. According to World Health Organization (WHO), anemia in girl teenager is still quite high, prevalence of anemia in the world ranges from $40-88 \%$ (1). The population of adolescents (10-19 years) in Indonesia is $26.2 \%$ consisting of $50.9 \%$ male and $49.1 \%$ female (2). Girls teenagers are one of the groups who are prone to anemia. Girls teenagers are at an increased risk of anemia compared than male teenagers because, first reason is girls teenagers every month have menstrual cycles. In addition, girls teenagers pay more attention to changes in body size and physical appearance so that the behavior or eating habits are often wrong, such as limiting the intake of food, especially animal foods which is sometimes considered a high-fat diet and can lead to obesity, causing the body to lack essential substances such as iron (3). During this countermeasures anemia is more focused on the group of pregnant women with the provision of tablets plus blood (TTD). Anemia in pregnant women mayaffect the mother and the baby can cause high maternal mortality (MMR). Prevention of anemia in pregnant women is better if the implementation of it, doing before the pregnancy or before marriage. Women of childbearing age and especially bride and groom are an appropriate targets in the prevention of anemia. The fertile age in women is a good time for women to prepare themselves physically and mentally to be healthy and not anemic, so it can 
be hoped getting a healthy baby (4). Pregnancy in adolescence age also gives a long effect of causing maternal death, infant, or the risk of giving birth to a baby with LBW (Low Birth Weight).

According to data from Riskesdas in 2013, the prevalence of anemia in Indonesia is $21.7 \%$ with $5-14$ years old anemia patients $26.4 \%$ and $18.4 \%$ of patients aged 15-24 years (5). Based on data from Bantul Health Office, the incidence of pregnant women's anemia in 2010 (23\%) until 2014 (29\%) fluctuated with the tendency of an increase so it was necessary to optimized the distribution of blood tablets (6). Prevalence of pregnant woman's anemia in Bantul Regency area in year 2013-2015 which have increase especially in Sedayu II Community Health Center $(50,21 \%)$, Pleret Health Center $(37,83 \%)$, Bambanglipuro Public Health Center (42.42\%), Bantul I Public Health Center (16.05\%), Puskesmas Bantul II (48.09\%), Puskesmas Jetis I (29.29\%), Puskesmas Pajangan (31.28\%), Sedayu I Community Health Center (37.05\%) and Puskesmas Srandakan (24.94\%). Based on Bhninekasari research the prevalence of anemia in bride candidate in Bantul Regency is 26\% (7).

One of the efforts to overcome the anemia's problem is by increasing the absorption of iron by improving the quality of food menu, that is by consuming fish, chicken, and foods that contain lots of vitamin $\mathrm{C}$. And reduce the consumption of $\mathrm{Fe}$ such as (tannin, phytate and oxalic acid). Based on the descriptions described above, the researcher will examine more about the relationship between $\mathrm{Fe}$ intake and Fe inhibitor with the incidence of anemia in the bride candidate in Bantul Regency.

\section{RESEARCH METHODS}

The type of this research is observational research using cross sectional design, which is implemented in Puskesmas Bantul District Special Province of Yogyakarta. Caten data is obtained from Puskesmas which are contained inclusion and exclusion criteria. The subjects of this study were caten with age 19-40 years, both anemic and non anemic. The data is collected that covers: data on iron intake, inhibitor Fe (tannins, phytate and oxalate) and levels Hemoglobin. Besides, data also is collected used data on the characteristics of respondents (name, age, education, employment, TB and BB). Interview respondents were based on SQFFQ in intake last 1 month.

Data analysis used SPSS program package was done gradually, that is by univariate analysis to know the characteristic of respondent, and bivariate to know the relation between independent variable and dependent variable by using T-test because the data is not normally distributed so finally used mann whitney data.

\section{RESULT AND DISCUSSION}

\section{Characteristics of Respondent}

Characteristics of respondents in this study included age, education, occupation and nutritional status, as in table 1.

Table 1. Characteristics of respondents $(n=68)$

\begin{tabular}{lcc}
\hline \multicolumn{1}{c}{ Characteristics } & N & $\%$ \\
\hline Age (years) & & \\
$\quad<20$ & 4 & 5.9 \\
$20-35$ & 61 & 89.7 \\
$>35$ & 3 & 4.4 \\
Education & & \\
$\quad$ Primary School+Junior High School & 15 & 22.1 \\
$\quad$ Senior High School + College & 53 & 77.9 \\
$\quad$ Occupation & & \\
$\quad$ Not Working & 5 & 7.4 \\
$\quad$ Private Employee & 52 & 76.5 \\
$\quad$ Enterpreuner & 9 & 13.2 \\
$\quad$ Others & 2 & 2.9 \\
Body Mass Index (kg/m ${ }^{2}$ ) & \multicolumn{2}{c}{} \\
$\quad<18.5$ (underweight) & 16 & 23.5 \\
18.5-22.9 (normal) & 37 & 54.4 \\
$\geq 23$ (overweight/obesity) & 15 & 22.1 \\
\hline Total & 68 & 100 \\
\hline
\end{tabular}

Distribution of respondents based on age characteristics was showed that the respondents most aged 20-35 years were 61 people (89.7\%). According to the type of work of the respondents, most of the last education of the respondents was graduated from SMA / SMK-PT, there were 53 people $(77.9 \%)$. Meanwhile, when viewed from the side of the job, mostly of respondents were private 
employees, there were 52 people $(76.5 \%)$, and for nutritional status, most of the respondents had good nutrition, there were 37 people (54.4\%). The Age of respondents were divided into 3 categories, there were $<20$ years old, ages between 20-35 years old and $>35$ years old. Respondents of this study were dominated women with ages range 20-35 years, there were 61 people (89.7\%). Ages range 20-35 years was the most appropriate age to marry for women, because in that range the physical and mental state of a woman was ready to marry and prepare to be a healthy mother and not anemic(8).

But usually women who will get married did diet to make the body looks slim. This diet generally was done by reducing the daily meals. In fact, women who are getting married did not need to diet to look slim, because based on research, there were $34.6 \%$ of bride and groom who have BMI under normal and lean (9). If the prospective bride was on a diet for a long time, then the intake of nutrients from food was not in accordance with the needs of the body which ultimately can cause anemia, both in the bride with normal nutritional status and nutritional status of skinny. In addition, later on can also result in health status when conception and childbirth (10).

Education respondents were divided into two, based on the current government program, namely compulsory nine years of education, respondents who graduated from elementary school - junior high school education classified and graduated from high school / vocational high school was classified as higher education. Most of the respondents, $77.9 \%$ (53 persons) were included in the higher education category while the respondents included in the lower education were $22.1 \%$ (15 people). Nowadays, information about anemia was not only obtained from formal education. Information about anemia can be obtained from television, radio, newspapers, and health personnel and this information was easily accessible to respondents. It was expected that with the higher level of education, knowledge and awareness of respondents about anemia will be higher, including knowledge about the nutrition in anemia. The existence of knowledge about nutrition was expected to create a pattern of healthy eating habits (11).
The type of respondent's work was divided into four categories, there were IRT, private employees, self-employed, and others. Most of the respondents worked some private employees, there was $76.5 \%$ (52 people). Work was one indicator of socioeconomic level, it was expected that the higher the economic level was same meaning with the better the quality of one's health and nutrition (12).

\section{Analysis of Univariat}

\section{Iron intake}

Iron intake and $\mathrm{Fe}$ inhibitors were measured by the SQFFQ form. Result of SQFFQ was processed used Nutri Survey to determine the amount of nutrients consumed by respondents. From 68 respondents, the average iron intake was $8.75 \mathrm{~g} \mathrm{(} \pm 11.71)$, with a minimum intake of 1.54 grams and a maximum of 82.66 grams. Iron intake percentage based on the average can be seen in the table 2 as follows:

Table 2 Percentage of Iron intake based on average intake and AKG

\begin{tabular}{lcccc}
\hline \multicolumn{1}{c}{ Intake } & Mean & $\mathbf{8 . 7 5}$ & \multicolumn{2}{c}{ AKG 26 g } \\
\hline Intake & $<8.75$ & $\geq 8.75$ & $<26$ & $\geq 26$ \\
Fe & $72.1 \%$ & $27.9 \%$ & $94.1 \%$ & $5.9 \%$ \\
\hline
\end{tabular}

Based on the average iron intake in table 2 , iron intake was grouped into 2 groups for each intake, which was above average and below average intake per day. There were 49 respondents $(72,1 \%)$ who consumed below average iron intake and compared with AKG there were 64 respondents $(94.1 \%)$ who consumed iron intake below the average intake per day.

\section{Intake of Iron Absorbing Inhibitors (Tannins, Fitates, and Oxalates)}

Based on food intake obtained with SQFFQ, and processed used FP2 it was known intake of each type of food and the average amount consumed per day. Average food ingredients consumed per day then calculated the amount of tannin, fitat and oksalat intake. Distribution of respondents based on tannin, fitat and oksalat intake can be seen in table 3 below 
Table 3. Mean of tannin intake, phytate, and oxalate intake average intake ( $\mathrm{mg} / \mathrm{hr})$

\begin{tabular}{lc}
\hline \multicolumn{1}{c}{ Intake } & $\begin{array}{c}\text { Mean of intake } \\
\text { (mg/day) }\end{array}$ \\
\hline Tanin & $64.1 \pm 11.482$ \\
Fitat & $6202.6 \pm 6919.20$ \\
Oksalat & $160.5 \pm 168.69$ \\
\hline
\end{tabular}

Based on the average of tannin, phytate and oxalate intake in the above table, the intake of inhibitor was grouped into 2 groups for each inhibitor, which was above average and below average daily intake. There were 67 respondents $(98.5 \%)$ who consumed tannins less than the average daily intake, 41 respondents (60.3\%) consumed less than average daily intake, and 44 respondents $(64.7 \%)$ which consumes less than average oxalate. Of all intake of inhibitors there is less than average intake.

\section{Anemia Occurrence}

One indicator of anemia assessment was hemoglobin levels. In this study examination of

Table 4. Frequency of anemia occurrence

\begin{tabular}{lcc}
\hline \multicolumn{1}{c}{ Anemia } & $\mathbf{n}$ & $\mathbf{\%}$ \\
\hline Anemia $<12 \mathrm{~g} / \mathrm{dL}$ & 30 & 44.1 \\
Not anemia $\geq 12 \mathrm{~g} / \mathrm{dl}$ & 38 & 55.9 \\
Total & $\mathbf{6 8}$ & $\mathbf{1 0 0}$ \\
\hline
\end{tabular}

hemoglobin levels used the method Hemochroma plus known parameters for the occurrence of anemia, which was said to anemia if the $\mathrm{Hb}$ level $<12 \mathrm{~g} / \mathrm{dl}$ and not anemia if the $\mathrm{Hb}$ level $\geq 12 \mathrm{~g} /$ dl. Comparison of the number of anemia and non anemia can be seen in table 4 below

Based on table 4 , it was known that $44.1 \%$ (30 people) of respondents suffer from anemia. The hemoglobin levels based on the average respondent $(\mathrm{n}=68)$ were $12.13 \mathrm{~g} / \mathrm{dl}( \pm 1.445)$.

\section{Analysis of Bivariat}

Based on the normality test data used kolmogorov smirnov known that the data of iron intake was not normally distributed, so the different test using mann whitney, can be seen in table 5

Table 5. Average respondents intake

\begin{tabular}{lccc}
\hline \multicolumn{1}{c}{ Intake } & Anemia & Not anemia & $\boldsymbol{p}^{*}$ \\
\hline Fe & 9.84 & 7.88 & 0.387 \\
Tannin & 5.08 & 7.46 & 0.512 \\
Phytate & 7.83 & 4.91 & 0.335 \\
Oxalate & 1.88 & 1.38 & 0.537 \\
\hline
\end{tabular}

*test using mann whitney

The analysis of the relationship (chi square) will use the median value as a cut off. The results of the analysis of the relationship between iron with the incidence of anemia can be seen in table 6 below

Table 6. Relationship between food intake and the incidence of anemia

\begin{tabular}{|c|c|c|c|c|c|c|c|}
\hline \multirow{2}{*}{ Intake } & \multicolumn{2}{|c|}{ Anemia } & \multicolumn{2}{|c|}{ Not anemia } & \multirow{2}{*}{$\mathbf{n}$} & \multirow{2}{*}{ Total } & \multirow{2}{*}{$\%$} \\
\hline & $\mathbf{N}$ & $\%$ & $\mathbf{N}$ & $\%$ & & & \\
\hline \multicolumn{8}{|l|}{ Iron } \\
\hline Low & 14 & 41.2 & 20 & 58.8 & 34 & $100 \%$ & 0.625 \\
\hline High & 16 & 47.1 & 18 & 52.9 & 34 & $100 \%$ & \\
\hline \multicolumn{8}{|l|}{ Tannin } \\
\hline Low & 17 & 50.0 & 17 & 50.0 & 34 & $100 \%$ & 0.329 \\
\hline High & 13 & 38.2 & 21 & 61.8 & 34 & $100 \%$ & \\
\hline \multicolumn{8}{|l|}{ Phytate } \\
\hline Low & 14 & 43.8 & 18 & 56.2 & 32 & $100 \%$ & 0.954 \\
\hline High & 16 & 44.4 & 20 & 55.6 & 36 & $100 \%$ & \\
\hline \multicolumn{8}{|c|}{ Oxalate } \\
\hline Low & 16 & 47.1 & 18 & 52.9 & 34 & $100 \%$ & 0.625 \\
\hline High & 14 & 41.2 & 20 & 58.8 & 34 & $100 \%$ & \\
\hline
\end{tabular}

*Test used Chi-Square 
The relationship between iron intake and the incidence of anemia

The intake of iron from the respondents was divided into 2 groups, high intake if $\geq$ median 4,5550 $\mathrm{g}$ and low intake if <of median 4,5550 g. Iron intake in the study was obtained based on interview results used SQFFQ form then the list of food interview results processed used Nutri Survey program package, the results of this calculation further in the search for the average value, based on the normality test data used kolmogorov smirnov known that the data from the intake of iron was not distributed normal, so the different test used mann whitney.

Table 5 shows that the average iron intake with different test of mann whitney anemia is 9.84 with $p=0.387$ which means there was no significant correlation between intake of $\mathrm{Fe}$ with the incidence of anemia. While the tables of chi square analysis with median value, based on the results of research on iron intake, it was known that the percentage of anemia was higher in the group of respondents who have a high iron intake compared with a low intake of $47.1 \%$.

Statistically, there was no significant correlation between iron intake and the incidence of anemia ( $p$ $=0,625(p>0,05)$ The result of this research is in line with Bhinnekasari research, which states that iron consumption of respondents is not significant with hemoglobin $(p=0.075)(7)$.

When we interviewed with the questionnaire, most respondents said that they did not like animal protein and most of them rarely consumed protein from animals, and enonomic factors as the reason. This causes the intake of iron below the average intake per day (13). this caused of the consumption of food that was less balanced so it can interfere the absorption of iron in the body. Most of the respondents consumed more iron-inhibiting foods, which tended to affect the absorption of Fe (13). Most of the iron nutritional anemia was caused by food eaten with less iron, especially in the form of iron hem, in addition to women due to blood loss during menstruation (14).

The results of this study were also in line with the study (Hidayanti, et al), which states that there was no relationship between the level of iron consumption with the incidence of anemia in young women in SMANegeri 1 District Jatibarang, Brebes regency, with $p=0,592$ (15). The significance of the results of this study can be caused by the low absorption of iron in the body (the habit of drinking tea after meals and before meals, still the lack of consumption of animal protein). The possibility can be caused by anemic respondents have been in counseling by health workers at Puskesmas at TT injection, so it can improve the intake of food, especially animal protein high in iron.

\section{The relationship between Tanin intake with the incidence of anemia}

The tannin intake of the respondents was divided into 2 groups, high intake if $\geq$ median 0.6150 $\mathrm{mg}$ and low intake if <median $0.6150 \mathrm{mg}$.

Tanin intake in the study was obtained based on the results of interviews used SQFFQ form, then the food list of interviews processed used FP2 program package, the results of this calculation further in searching the average value, based on the normality test data used kolmogorov smirnov known that the data from tannin intake was not normally distributed, so the different test used mann whitney.

Table 5 showed that the average intake of Fitat with different test of mann whitney anemia was higher than that which was not anemia was 7.83 with $(p=$ 0.335 ) which there was no significant relationship between intake of Fitat and the incidence of anemia. While chi square table with median value, based on result of research fitat known that percentage of anemia with phytate intake was higher than low $(44,4 \%)$. This study was not in line with the theory that consumed inhibitors (tannins) can lower $\mathrm{Hb}$ levels. This study was in line with the study. The study said that the possibility that maked the habit of taking iron absorption inhibitors unrelated to the occurrence of anemia was that respondents jail consumption so that iron can be absorbed first by the small intestine and there was no attraction between the intake of iron with tannins that will inhibit the absorption of substances the iron. Kasdan said that another possibility of respondents likes to eat an iron absorbing inhibitor that has been packaged. For example, packaged tea has undergone several 
processes that may not be as high as tannin content in the original tea (16).

In this study, others respondent said that there were some respondents conduct jail consumption of iron servants so that iron intake can be absorbed by the body. Another part of the respondents consumed Fe inhibitors with packaged or ready-to-drink beverages. This research was in accordance with the statement of Kasdan.

Tanin was a polyphenol compound contained in tea, coffee and several types of vegetables and fruits. Tanin inhibited iron absorption by binding it (14). Compared with meat, tea can reduce $50 \%$ iron absorption because the dissolved form of iron associated with tannins (17). The absorption of iron and food contained maize was about 4.6 to $24.7 \%$. This absorption will be lower (2.1\%) if consumed with tea. The addition of 50 to $100 \mathrm{mg}$ Vitamin C leads to an increase in iron absorption, but this increase will decrease in the presence of tea. Tea inhibiting effects will disappear with the consumption of 250-500 mg of Vitamin C (18).

\section{The relationship between intake Fitat with the incidence of anemia}

Sputum intake of the respondents was divided into 2 groups, high intake if $\geq$ median $5171.53 \mathrm{mg}$ and low intake if <median $5171.53 \mathrm{mg}$.

Fitat intake in the study was obtained based on the results of interviews used SQFFQ form, then the list of food interview results processed used FP2 program package, the results of this calculation further in the search for the average value, based on the test of data normality using kolmogorov smirnov known that data from phytate intake was not normally distributed, so the different test used mann whitney.

Table 5 showed that the average intake of Fitat with different test of mann whitney anemia was higher than that which was not anemia was 7.83 with $(p=0.335)$ which there was no significant relationship between intake of Fitat and the incidence of anemia. While chi square table with median value, based on result of research fitat known that percentage of anemia with phytate intake was higher than low $(44,4 \%)$.
Statistically, there was no significant relationship between phytate intake and the incidence of anemia. ( $p=0.954)$, because most respondents who had been interviewed used SQFFQ consumed more complex carbohydrate foods. The possibility of such intake, iron absorption was hampered by phytate content, if taken together. With reduced iron absorption, due to these inhibiting factors, the amount of ferifin will also decrease which affects the decrease in the amount of iron that will be used for hemoglobin synthesis and replace damaged hemoglobin. This is one factor causing low levels of hemoglobin in the blood (18).

In this study the main food respondents were rice, corn, cassava and wheat, where the food was a food containing phytate. Fitates were widely present in wheat and whole grains, although in small amounts, phytate can reduce iron absorption (19). Fitates were widely present in wheat and whole grains, although in small amounts, phytate can reduce iron absorption (14). According to Counsell, J.N., and Horning, D.H, a very common phytate in vegetables prevented the reduction of the ferric form to ferro which would result in an iron barrier by an insoluble iron complex (20).

\section{The relationship between oxalate intake and the incidence of anemia}

Oxalate intake of the respondents was divided into 2 groups, high intake if $\geq$ median $133.38 \mathrm{mg}$ and low intake if <median $133.38 \mathrm{mg}$.

Oxalate intake in the study was obtained based on the results of interviews used SQFFQ form, then the list of food interview results processed used FP2 program package, the results of this calculation further in the search for the average value, based on the test of data normality used kolmogorov smirnov known that the data from the oxalate intake was not normally distributed, so the different test used mann whitney.

Table 5 showed that the mean anal oxalate intake was higher than the non-anemic $1.88(p=$ 0.537 ) where there was no significant relationship between oxalate intake and the incidence of anemia. While the table 6 chi square analysis with median value, based on the results of oxalate studies known 
that the percentage of anemia with oxalate intake was lower than that of $47.1 \%$. Statistically, there was no significant relationship between phytate intake with the incidence of anemia. This can be seen at the value of $p=0.625$.

This study was in line with the research of Susilo and Hadi, about the relationship of iron intake, tannin, phytate, oxalate and calcium with maternal hemoglobin concentration in Bantul regency of DIY Province, which said there was no significant relationship between oxalic acid intake and Hemoglobin with $p>0.05$ (21).

Content of high oxalic acid in foodstuffs had a negative effect on iron absorption. Foods contained oxalic acid include spinach, potatoes, raisins, cabbage, cauliflower, lettuce, green beans, peas, tea, coffee, chocolate, apples and tomatoes. High oxalate content can be derived by cooking and fermentation processes (14).

\section{CONCLUSION AND SUGGESTION}

\section{Conclusion}

Based on the results of research conducted there were 68 respondents can be drawn the following conclusions:

a. The prevalence of anemia in bride candidates in Bantul District was $44.1 \%$

b. There was no significant relationship between $\mathrm{Fe}$ intake and the incidence of anemia

c. There was no significant association between $\mathrm{Fe}$ (Tanin, Fitate and Oxalate) inhibitors with the incidence of anemia

\section{Suggestion}

a. For Health Worker

Health workers at Puskesmas to conduct a counseling program every month, so that the bride prepared a sufficient intake to avoid anemia

b. For Further Research

For further research, it was expected to conduct research on Fe inhibitors with ready-to-serve or packaged beverages, since the content in each package differs from the original content c. For further research to add iron supplements on the questionnaire so that data obtained more valid.

\section{REFERENCES}

1. WHO. Global Nutrition Target 2025 Anemia Policy Brief. Diakses pada tanggal 3 Juli 2015 dari,www.who.int/entity/nutrition/publications/ globaltargets2025_policybri ef_anaemia/en/ -29k (2013).

2. Kemenkes RI. Bantuan Operasional Kesehatan. Jakarta : Kemenkes RI (2013).

3. Dieny, F. Permasalahan Gizi pada Remaja Putri. Yogyakarta: Graha IImu (2014).

4. Argana,G., Kusharisupeni dan Utari Diah. Vitamin C Sebagai Faktor Dominan Untuk Kadar Hemoglobin Pada Wanita Usia 20 - 35 Tahun. Jurnal Kedokteran Trisakti, 23 (1)(2004)

5. Kementerian kesehatan RI. Pusat Data dan Informasi. Jakarta selatan (2014).

6. DINKES Bantul. Data prevalensi anemia ibu hamil. Yogyakarta (2014).

7. Bhinnekasari, B. M. Hubungan antara Asupan Protein, Zat Besi dan Vitamin C terhadap Kejadian Anemia pada Calon Pengantin di Wilayah Bantul. Skripsi, Universitas Gadjah Mada Yogyakarta (2012).

8. Argana, Komang: 2009, Perilaku Organisasi, Graha IImu, Yogyakarta

9. Arisman. 2010. Gizi Dasar Kehidupan. Jakarta: Penerbit Buku Kedokteran EGC

10. Novitasari, Suci. 2014. Hubungan Tingkat Asupan Protein, Zat Besi, Vitamin C dan Seng dengan Kadar Hemoglobin pada Remaja Putri di SMA Batik 1 Surakarta. Karya Tulis IImiah Universitas Muhamadiyah Surakarta.

11. Susanti, 2013, Pengaruh Kompensasi, Lingkungan Kerja, Gaya Kepemimpinan dan Motivasi Terhadap Kinerja Karyawan Bagian Akutansi dan Keuangan. Fakultas Ekonomi, Universitas Maritim Raja Ali Haji. Tanjungpinang.

12. Priswanti. Hubungan Ketersediaan Pangan Keluarga Dan Tingkat Konsumsi Energi, Protein, $\mathrm{Fe}$, Asam Folat, Vitamin B12 dengan Kejadian 
Kurang Energi Kronis (Kek) Dan Anemia Pada Ibu Hamil. Semarang: Universitas Diponegoro; 2004.

13. Gunatmaningsih D. 2007. Faktorfaktor yang berhubungan dengan kejadian anemia pada remaja putri di SMA Negeri. Bogor: Fakultas Ekologi Manusia, Institut Pertanian Bogor.

14. Almatsier, S. Prinsip Dasar Ilmu Gizi. Gramedia Pustaka Utama. Jakarta (2010).

15. Hidayanti, dkk. Gambaran Pola Konsumsi Zat Pelancar dan Zat Penghambat Absorpsi Zat Besi serta Kadar Hemoglobin pada wanita prakonsepsi di Kota Makasar. [JURNAL]. Kesehatan.

16. Kasdan T.S, Mahan L.K\&Escott-Stump, S. (Ed). (2009). Nutritional Care in Anemia. Food, Nutrition and Diet Therapy. (Pennsylvania:Saunders Company).

17. Husaini, MA. 2009. Study nutritional anemia an assessment of information.Complication for supporting and formulating national policy and program. Jakarta: Direktorat Gizi dan Pusat Penelitian dan Pengembangan Departemen Kesehatan RI.

18. De Maeyer, E. M. Pencegahan dan Pengawasan Anemia Defisiensi Besi. Alih Bahasa: Arisman, MB, Widya Medika: Jakarta. 2003. 30-34

19. Noonan, S. C. and G. P. Savage. 1999. Oxalate Contents in Foods and Its Effects on Human. Asia Pacific. J. Clinic Nutrional. 81(1): 64-67.

20. Counsell, J.N., dan Horning, D.H. (1981). Vitamin C. London: Applied Science Publishers. Hal. 123-124.

21. Susilo dan Hadi. Hubungan antara zat Besi dan Inhibitor-Nya, sebagai prediktor kadar hemoglobin ibu hamil di Kabupaten Bantul Provinsi DIY. Akademik Gizi (POLTEKES), Yogyakarta. Bagian Ilmu Kesehatan Masyarakat, FK UGM, Yogyakarta (2002). 